\title{
Comparison of flight design of Asian honeybee drones
}

\author{
Sarah E. RADLOFF ${ }^{a *}$, H. Randall HEPBURN ${ }^{b}$, Gudrun KOENIGER $^{c}$ \\ ${ }^{a}$ Department of Statistics, Rhodes University, Grahamstown, South Africa \\ b Department of Zoology and Entomology, Rhodes University, Grahamstown, South Africa \\ c Institut für Bienenkunde, Oberursel, Germany
}

(Received 30 May 2002; revised 30 September 2002; accepted 12 December 2002)

\begin{abstract}
The excess power index (integrating body dry mass, thorax-to-body dry mass and wing surface area) was compared in drones of seven Asian Apis species. There are two statistically distinct groups of drones: drones of the dwarf honeybees form one class, all other Asian species belong to the second. Drones of dwarf honeybees have a $36 \%$ ergonomic advantage in power availability and $20 \%$ advantage in available excess power over all other drones. Comparisons of flight dimensions between conspecific workers and drones show a highly statistically significant sexual dimorphism for flight. Although drones of all seven tested species are always bigger than their workers their excess power index is some $15 \%$ better. It is suggested that prowess of flight in drones is driven by the need to compete and mate with queens flying high in the air while worker bees forage nectar and pollen on flowers.
\end{abstract}

body dry mass / wing surface / excess power / Apis drones / sexual dimorphism

\section{INTRODUCTION}

While the honeybee thorax powers flight, substantial differences in the ratio of flight engine mass (thorax) to that of fuselage (whole body) have large aerodynamic effects on flight. As a consequence and from dimensional considerations alone, ultimate flight capacity depends on the maximum excess power available to a honeybee over that required to maintain equilibrium in steady level flight (Hepburn et al., 1998a, b). As it transpires, from an engineering perspective, worker honeybees of the Asian species of Apis L. comprise three design classes based on wing loading, engine size and excess power index (Radloff et al., 2001).

Worker and drone honeybees are both strong flyers but all they share in common on the wing are those flights associated with cleansing, swarming and absconding (Koeniger, 1991). Worker flight is mainly directed towards short distance foraging and carrying home extra and relatively heavy loads (nectar and pollen); drone flight to longer distance congregation areas. Given the generally high levels of polyandry in honeybees and that a drone can mate but once, drones must be under severe selective pressure for aerodynamic prowess in the mating comets which have been observed in A. cerana, A. koschevnikovi and A. dorsata (Gries, 1997). Thus the drone flight mechanism is of interest to considerations of conspecific sexual dimorphism for flight (in a swarming or absconding context) but particularly in the context of mating. We report the results of analyses of these variables for several Asian honeybee species.

\footnotetext{
* Correspondence and reprints

E-mail: s.radloff@ru.ac.za
} 
Table I. Means and standard deviations (sd) of dimensional characteristics of drone honeybee flight.

\begin{tabular}{|c|c|c|c|c|c|c|c|c|c|c|c|c|c|}
\hline \multirow[t]{2}{*}{ Species } & \multirow[t]{2}{*}{$\begin{array}{l}\text { No. of } \\
\text { drones }\end{array}$} & \multicolumn{2}{|c|}{$\begin{array}{l}\text { Whole body } \\
\text { mass } \\
(\mathrm{mg})\end{array}$} & \multicolumn{2}{|c|}{ Thoracic mass } & \multicolumn{2}{|c|}{$\begin{array}{l}\text { Thorax/body } \\
\text { mass ratio }\end{array}$} & \multicolumn{2}{|c|}{$\begin{array}{c}\text { Wing surface } \\
\text { area } \\
\left(\mathrm{mm}^{2}\right)\end{array}$} & \multicolumn{2}{|c|}{$\begin{array}{l}\text { Wing loading } \\
\left(\mathrm{mg} / \mathrm{mm}^{2}\right)\end{array}$} & \multicolumn{2}{|c|}{$\begin{array}{c}\text { Excess power } \\
\text { index }\end{array}$} \\
\hline & & mean & sd & mean & sd & mean & sd & mean & sd & mean & sd & mean & sd \\
\hline A. cerana & 49 & $17.6 \mathrm{~b}$ & 2.8 & $10.0 \mathrm{~b}$ & 1.6 & $0.57 \mathrm{c}$ & 0.02 & $63.2 \mathrm{a}$ & 3.1 & $0.28 b$ & 0.04 & $1.10 \mathrm{~b}$ & 0.11 \\
\hline A. nigrocincta & 14 & $18.2 \mathrm{~b}$ & 3.8 & $9.9 \mathrm{ab}$ & 1.9 & $0.55 \mathrm{ab}$ & 0.02 & $66.0 \mathrm{a}$ & 3.6 & $0.27 b$ & 0.05 & $1.06 \mathrm{ab}$ & 0.15 \\
\hline A. koschevnikovi & 15 & $24.8 \mathrm{c}$ & 1.7 & $12.8 \mathrm{c}$ & 0.9 & $0.52 \mathrm{a}$ & 0.02 & $81.5 b$ & 2.5 & $0.30 \mathrm{~b}$ & 0.02 & $0.94 \mathrm{a}$ & 0.06 \\
\hline A. dorsata & 40 & $36.8 \mathrm{~d}$ & 6.2 & $20.1 d$ & 3.5 & $0.55 b$ & 0.03 & $137.0 \mathrm{c}$ & 5.7 & $0.27 \mathrm{~b}$ & 0.04 & $1.07 \mathrm{~b}$ & 0.12 \\
\hline A. d. binghami & 4 & $43.6 \mathrm{~d}$ & 4.8 & $23.4 d$ & 2.8 & $0.54 \mathrm{ab}$ & 0.01 & $137.9 \mathrm{c}$ & 8.1 & $0.32 b$ & 0.02 & $0.96 \mathrm{ab}$ & 0.02 \\
\hline A. florea & 7 & $12.9 \mathrm{a}$ & 0.7 & $7.3 \mathrm{a}$ & 0.4 & $0.575 \mathrm{c}$ & 0.01 & $66.6 \mathrm{a}$ & 3.7 & $0.19 a$ & 0.01 & $1.28 \mathrm{c}$ & 0.05 \\
\hline A. andreniformis & 8 & $11.3 \mathrm{a}$ & 2.1 & $6.9 \mathrm{a}$ & 1.3 & $0.61 \mathrm{~d}$ & 0.02 & $64.2 \mathrm{a}$ & 6.4 & $0.18 \mathrm{a}$ & 0.02 & $1.46 \mathrm{c}$ & 0.11 \\
\hline & & \multicolumn{2}{|c|}{$\begin{array}{c}\mathrm{H}=113.2 \\
(6.137) \mathrm{df} \\
P<0.0001\end{array}$} & \multicolumn{2}{|c|}{$\begin{array}{c}\mathrm{H}=112.6 \\
(6.137) \mathrm{df} \\
P<0.0001\end{array}$} & \multicolumn{2}{|c|}{$\begin{array}{c}\mathrm{H}=69.3 \\
(6.137) \mathrm{df} \\
P<0.0001\end{array}$} & \multicolumn{2}{|c|}{$\begin{array}{c}\mathrm{H}=109.9 \\
(6.137) \mathrm{df} \\
P<0.0001\end{array}$} & \multicolumn{2}{|c|}{$\begin{array}{c}\mathrm{H}=46.1 \\
(6.137) \mathrm{df} \\
P<0.0001\end{array}$} & \multicolumn{2}{|c|}{$\begin{array}{c}H=64.6 \\
(6.137) \mathrm{df} \\
P<0.0001\end{array}$} \\
\hline
\end{tabular}

$\mathrm{a}, \mathrm{b}, \mathrm{c}=$ Means with same letter do not differ significantly $(P>0.05)$.

\section{MATERIALS AND METHODS}

\subsection{Samples}

Drone honeybees were collected in southeast Asia and preserved in ethanol for subsequent analysis. The species examined and the numbers of colonies and individuals measured (given in brackets) are as follows: A. cerana Fabr. (7 colonies, 49 drones), A. florea Fabr. (1, 7), A. andreniformis $\mathrm{F}$. Smith $(1,8)$, A. koschevnikovi v. Buttel-Reepen $(2,15)$, A. nigrocincta $\mathrm{F}$. Smith $(2$, 14), A. dorsata dorsata Fabr. (4, 40), A. dorsata binghami Cockerell $(1,4)$ (hereinafter referred to as A. dorsata and A. d. binghami). The drones were dissected to remove their hindguts because gut contents of fed bees may greatly distort weight values. Dry weight values of the hindguts for starved bees were previously shown to contribute about $10 \%$ of total dry body mass in different subspecies of honeybees (Hepburn et al., 1998a, b) and were simply omitted from further calculations. The drones were then cut to separate the thorax from the head and abdomen after which all parts were weighed when they achieved constant dry mass. The wings of each drone were projected on a digitizing tablet and scanned to measure total surface area.

\subsection{Excess power index}

The excess power index $(\mathrm{EPI})$ is defined as $\left(\mathrm{r}^{2} / \mathrm{W}\right)$ where $\mathrm{W}$ is the wing loading and $\mathrm{r}$ is the ratio of the thorax mass to total mass (Hepburn et al., 1998a, b, 1999). All calculations are based on constant dry mass values. A note of caution pertains to "engine mass": whole thoracic mass is treated as "engine mass" because the indirect flight muscles and the elastic cuticle operate together to power flight.

\subsection{Data processing}

The non-parametric Kruskal-Wallis procedure was used to test for significant differences in whole body mass, thorax mass, wing surface area, body mass ratio, wing loading and EPI colony means between the seven species because all these characteristics of flight failed tests of normality (Kolmogorov-Smirnov tests, $P<0.01$ ). Pairwise multiple comparisons between species were tested by means of Mann-Whitney U tests with Bonferroni adjustments to the level of significance. The MannWhitney $\mathrm{U}$ procedure was also used for testing flight dimension differences between drones and workers.

\section{RESULTS}

The results of the dimensional analysis of flight for honeybee drones include the means for total body mass, thorax mass, thorax-tobody mass ratio, wing surface area, wing loading and the excess power index (Tab. I). Tests for the comparisons of means showed significant differences among the species. There is a nearly four-fold difference in total body mass (dry weight) between the smallest (A. andreniformis and A. florea) and largest (A. dorsata 
Table II. Mean comparisons of flight dimensional characteristics of worker and drone honeybees for $A$. $d$. binghami, A. dorsata, A. koschevnikovi, A. nigrocincta, A. cerana, A. florea and A. andreniformis.

\begin{tabular}{lcccccc}
\hline Character & \multicolumn{2}{c}{ Drones } & & Workers* & Mann-Whitney U & $P$-value \\
& & & & & \\
& Clusters $^{\#}$ & Mean \pm sd & Clusters $^{\#}$ & Mean \pm sd & & \\
\hline Body mass & 4 & $24.2 \pm 10.5$ & 4 & $15.1 \pm 10.1$ & 1386.0 & $<0.0001$ \\
Thoracic mass & 4 & $13.3 \pm 5.6$ & 4 & $7.9 \pm 5.3$ & 1170.5 & $<0.0001$ \\
Thorax/body mass ratio & 4 & $0.56 \pm 0.03$ & 2 & $0.52 \pm 0.02$ & 977.0 & $<0.0001$ \\
Wing surface area & 3 & $89.5 \pm 33.6$ & 3 & $47.2 \pm 28.1$ & 755.0 & $<0.0001$ \\
Wing loading & 2 & $0.27 \pm 0.05$ & 3 & $0.31 \pm 0.06$ & 1766.0 & $<0.0001$ \\
Excess power index & 3 & $1.10 \pm 0.17$ & 3 & $0.95 \pm 0.10$ & 1309.5 & $<0.0001$ \\
\hline
\end{tabular}

* Data for workers from Radloff et al. (2001).

\# Number of homogeneous groups of species found when using post-hoc multiple comparisons of means between species (Tab. I).

and A. d. binghami) drones. Moreover, the drones can be grouped into four fairly distinct total body mass groups. Thoracic dry mass varied just over three-fold and for this parameter the drones can also be divided into four statistically distinct groups (Tab. I).

The dimensional effects of these whole body and thoracic mass differences are clearly reflected in the "engine-to-aircraft" mass ratios. Those bees with the greatest engine to body mass are the smallest, A. andreniformis, followed by a group consisting of A. cerana, A. florea, A. nigrocincta, A. dorsata, A. d. binghami, and lastly A. koschevnikovi (Tab. I). Nonetheless the thorax/body mass ratio varies by only $15 \%$ across the drones $(0.52$ in $A$. koschevnikovi and 0.61 in A. andreniformis). The deviation from a mean ratio for all drones is only about $2 \%$ for all species except $A$. andreniformis and A. koschevnikovi (8\%).

In the case of total wing surface area the drones vary by over $50 \%\left(63 \mathrm{~mm}^{2}\right.$ in $A$. cerana to $138 \mathrm{~mm}^{2}$ in $A$. d. binghami). For this variable the drones form three statistical classes, the two giant bees (A. dorsata and A. d. binghami), A. koschevnikovi alone, and all the other species form the third class (Tab. I). Thus, changes in wing surface area among drones of different sizes scale vary differently from that of mass. These scaling differences are inevitably reflected in wing loading values; but, because loading is a ratio, statistical class differences are reduced and only two groups emerge from the analysis. The two dwarf bee drones, A. andreniformis and $A$. florea, have significantly lower wing loadings than the other five species. In terms of generating aerodynamic lift, this confers a $36 \%$ advantage in power availability to the dwarf drones.

The final ratio, the excess power index is a complex number encompassing all of the dimensions considered in one final product. In this analysis the EPI reflects only dimensional considerations but ultimately flight capacity must include combustion efficiency, horsepower and various kinematic properties of flight. In any event, differences in scaling come together with the EPI. For excess power there are two distinct groups of drones, the dwarf A. andreniformis and A. florea in one class and all others in a second class (Tab. I). Solely taking dimensions, the dwarf drones have a $20 \%$ advantage over the other drones in available excess power.

Comparisons of flight dimensions between conspecific workers and drones show that there is a highly statistically significant sexual dimorphism in characteristics related to flight (Tab. II, data from Radloff et al., 2001). Analyzing the species separately, with the single exception of $A$. koschevnikovi, all other conspecific workers and drones differ significantly from each other for EPI. There were no significant differences between workers and drones of $A$. dorsata and $A$. d. binghami for body mass and thoracic mass and no significant differences between workers and drones of A. dorsata and A. koschevnikovi for thorax/ body mass ratio. These differences are summarized using mean values in Table III. 
Table III. Mean comparisons of flight dimensional characteristics of worker ${ }^{\#}$ and drone honeybees.

\begin{tabular}{lccccccc}
\hline Character & cerana & nigrocincta & koschevnikovi & dorsata & $d$. binghami & florea & andreniformis \\
\hline Body mass & $* *$ & $* *$ & $* *$ & $\mathrm{~ns}$ & $\mathrm{~ns}$ & $* *$ & $* *$ \\
Thoracic mass & $* *$ & $* *$ & $* *$ & $\mathrm{~ns}$ & $\mathrm{~ns}$ & $* *$ & $* *$ \\
Thorax/body mass ratio & $* *$ & $* *$ & $\mathrm{~ns}$ & $\mathrm{~ns}$ & $*$ & $* *$ & $* *$ \\
Wing surface area & $* *$ & $* *$ & $* *$ & $*$ & $*$ & $* *$ & $* *$ \\
Wing loading & $* *$ & $* *$ & $\mathrm{~ns}$ & $*$ & $*$ & $*$ & $*$ \\
Excess power index & $* *$ & $* *$ & $\mathrm{~ns}$ & $* *$ & $* *$ & $* *$ & $* *$ \\
\hline
\end{tabular}

** $P<0.01, * P<0.05, \mathrm{~ns}=$ not significant.

\# Data for workers from Radloff et al. (2001).

For thoracic mass, whole body mass, and wing surface area the workers show a sevenfold variation against a three-fold one for the drones. As for the thorax/whole body mass ratio, the workers with the highest values (A. cerana and A. dorsata, 0.53 , Radloff et al., 2001) are only just on par with the drones with the lowest values (A. koschevnikovi). On average the drones have an energetically more economical wing loading ratio than do the workers. Coupled to the mass ratios, this results in the drones having a significantly enhanced final excess power index compared to workers, the former being $15 \%$ more economical. So although drones of all seven species are always bigger and heavier than their conspecific workers, they have correspondingly larger wing surface areas and hence lower wing loading and higher excess power indices than the worker bees (Tab. II).

\section{DISCUSSION}

Several factors may affect aerodynamic efficiency of honeybee flight, among them, variable body proportions, differences in mass specific flight metabolism (Coelho and Mitton, 1988; Harrison et al., 1996), ratios of direct and indirect muscle to thoracic skeleton (Dulta and Verma, 1987) and size and altitude (Hepburn et al., 2000). The excess power index assumes that all honeybee flight muscle is of equal combustion capacity per unit mass of muscle and that all bees fly at the same air density. Flight may be further modified by changes in wingbeat frequency, wing bending and angle of attack and other kinematic properties (Nachtigall, 1989 et seq.). Because few of the above factors have been quantified for drones, we have simplified the assumptions by holding them constant for purposes of discussion.

Assuming that the bees are flying under constant conditions, honeybee flight would be relatively insensitive to small differences in air density based on the low Reynolds numbers (Hepburn et al., 1998a, b). Thus, the excess power index can only be varied by changing the thorax/body mass ratio, improving wing loading or, a combination of both. With the exception of dwarf $A$. andreniformis, thorax/ body mass ratio is virtually constant in the other six species of drones so that the excess power index can only be improved by varying wing loading. These factors are reflected in the final excess power index values for which there are only two statistically distinct classes of drones, the highly efficient drones of the dwarf bees, A. andreniformis and A. florea in one class and the other species in a separate group (Tab. I).

Although it would be desirable to compare queen and drone flight in terms of sexual dimorphism, information on characteristics related to queen flight is not available. However, the difference in flight dimensions between conspecific drones and workers is so striking (Tab. II) that it invites speculations as to possible explanations for superior aerodynamic design in drone flight. Clearly, the primary function of drone flight is directed towards mating. Mating systems in honeybees are currently of considerable interest and now flying ability can be added to such debates (Koeniger et al., 2000; Palmer and Oldroyd, 2000).

If it is accepted on a priori grounds that there must be strong selective pressure on 
drones through competition to mate, then it is plausible that part of this pressure is directed to flight prowess in congregation areas. Flying ability must not be confused with speed as such. An ergonomically higher excess power index essentially provides reduced flight cost per unit time- which equates to the possibility of enhanced duration of flight. It appears to us that drones are evidently well designed from an ergonomic perspective. Because these inferences could be labeled as "adaptionist" speculations, another hypothesis is that workers were moulded by selection but drones retained their ancestral sizes (Ruttner, 1988). While these ideas are by no means mutually exclusive; it would be difficult to dismiss selective pressure on drone flight prowess when the odds of their possible success in a congregation area are considered.

Résumé - Comparaison des caractères de vol des mâles d'abeilles domestiques asiatiques. Chez les abeilles asiatiques du genre Apis, les ouvrières sont réparties en trois classes de caractères de vol basées sur la charge alaire, la taille du « moteur » et l'indice de réserve de puissance EPI (Radloff et al., 2001). Les qualités aérodynamiques des mâles subissent une pression sélective importante en raison de la concurrence qui existe sur les lieux de rassemblement de mâles, aussi le mécanisme de vol peut-il présenter un dimorphisme sexuel. Les caractères suivants ont été mesurés: masse corporelle totale sèche $\mathrm{MC}$, masse thoracique sèche MT, rapport $\mathrm{r}$ (MC/MT), surface de l'aile, charge alaire et EPI. Les résultats sont donnés dans le tableau I. Les mâles peuvent être regroupés en quatre classes en fonction de la MC et la MT. Les mâles les plus petits (A. andreniformis) ont la valeur de $r$ la plus grande, suivis par le groupe A. cerana, A. florea, puis A. dorsata, A. nigrocincta et A. d. binghami. A. koschevnikovi a la plus petite valeur de r. Les mâles peuvent être répartis en trois classes statistiques en fonction de la surface totale de l'aile et en deux classes seulement en fonction de la charge alaire: les abeilles naines (A. andreniformis et A. florea) ont des charges alaires nettement moindres que les cinq autres espèces. En termes de propulsion aérodynamique, cela confère aux mâles des abeilles naines un avantage de $36 \%$ pour la puissance disponible. Si l'on considère l'EPI les mâles des abeilles naines forment une classe, ceux des autres espèces une autre classe, et ils ont un avantage de $20 \%$ sur les mâles des autres espèces.

La comparaison des caractères de vol entre ouvrières et mâles pour l'ensemble des espèces montre qu'il existe un dimorphisme sexuel statistiquement hautement significatif (Tab. II). Le tableau III donne les seuils de signification des différences entre mâles et ouvrières pour chaque espèce. Les mâles ont un EPI significativement plus élevé que les ouvrières, de $15 \%$ pour certains.

Le dimorphisme sexuel dans les caractères de vol entre mâles et ouvrières de même espèce est frappant. La fonction première du vol des mâles est l'accouplement. Si l'on considère à priori qu'une forte pression de sélection doit s'exercer sur les mâles à travers la compétition pour s'accoupler, il est alors plausible qu'une partie de cette pression soit dirigée vers l'habileté à voler. Un indice de réserve de puissance élevé réduit les coûts de vol par unité de temps. Cela équivaut à une durée de vol plus longue et les mâles sont visiblement bien adaptés du point de vue ergonomique.

\section{Apis / mâle / masse corporelle / surface alaire / réserve de puissance / dimorphisme sexuel}

Zusammenfassung - Vergleich von Flugeigenschaften von Drohnen der asiatischen Honigbienen. Bei Arbeiterinnen der asiatischen Arten von Apis gibt es drei Klassifizierung der Flugeigenschaften: die Flügelbelastung, "Größe des Antriebsaggregates" und der Index für Kraftüberschuss (excess power index EPI), (Radloff et al., 2001). Da die aerodynamischen Eigenschaften von Drohnen auf Grund der Konkurrenz auf dem Drohnensammelplatz unter starkem selektiven Druck stehen, könnte der Flugmechanismus einen sexuellen Dimorphismus aufweisen. Drohnen wurden in Südostasien in Ethanol gesammelt. Die Därme der Drohnen wurden entfernt. Thorax, Kopf und Abdomen wurden gewogen, sobald sie eine konstante Trockenmasse aufwiesen. Die Gesamtfläche der Flügel wurde bestimmt. Der "excess power index" (EPI) ist als $\mathrm{r}^{2} / \mathrm{W}$ definiert ( $\mathrm{W}$ ist die Flügelbelastung, $r$ ist Thoraxmasse/Gesamtmasse). Nichtparametrische Tests und paarweise multiple Vergleiche wurden benutzt, um die Signifikanz der Unterschiede zu bestimmen.

Die Ergebnisse für Gesamtgewicht, Thoraxgewicht, das Verhältnis von Thorax-/Körpergewicht, Fügelfläche, Fügelbelastung und der EPI Index sind in Tab. I angegeben. Die Drohnen können in 4 recht distinkte Gewichtsklassen für Trockengewichte des gesamten Drohns und des Thorax eingeteilt werden. Hierbei zeigen sich bereits Unterschiede im Massenverhältnis "Antriebsaggregat-zu-Flugkörper". Die kleinsten Drohnen ( $A$. andreniformis) haben das relativ größte Verhältnis von Thorax-/Gesamtgewicht, gefolgt von der Gruppe A. cerana, A. florea, dann A. dorsata, A. nigrocincta, $A$. $d$. binghami. Das kleinste Verhältnis hat A. koschevnikovi. In Bezug auf die Flügelfläche bilden die Drohnen 3 statistische Klassen. Die Änderungen in der Flügelfläche variieren unabhängig vom Gewicht. Für die sich daraus ergebende Flügelbelastung reduzieren sich die statistischen Klassen auf 2 Gruppen: Drohnen der 
Zwerghonigbienen haben eine signifikant geringere Flügelbelastung als die anderen 5 Arten. Bezüglich der Erzeugung eines aerodynamischen Auftriebs entspricht dies bei den Zwerghonigbienen einem $36 \%$ Vorteil in der Verfügbarkeit von Kraft. Auch bei Betrachtung des EPI bilden die Zwerghonigbienen eine Gruppe und haben $20 \%$ Vorteil gegenüber den anderen Drohnen.

Vergleiche zwischen Arbeiterinnen und Drohnen aller Arten zusammengefasst zeigen einen statistisch hoch signifikanten sexuellen Dimorphismus in den Flugeigenschaften (Tab. II). Die statistischen Sicherungen der Unterschiede in den Flugeigenschaften bei Arbeiterinnen und Drohnen sind für die einzelnen Arten in Tabelle III gezeigt. Die besten Werte der Arbeiterinnen (A. cerana and A. dorsata) sind gerade gleich mit den schlechtesten Drohnenwerten (A. koschevnikovi). Drohnen haben einen signifikant besseren EPI als Arbeiterinnen, manche mehr als $15 \%$.

Der sexuelle Dimorphismus zwischen Drohnen und Arbeiterinnen innerhalb der Arten ist eindrucksvoll. Wenn man als wichtigsten Grund annimmt, dass es einen starken selektiven Druck durch die Paarungskonkurrenz im Flug gibt, wird plausibel, dass er z.T. in Richtung Fluggeschicklichkeit wirkt. Ein höherer EPI reduziert die Flugkosten pro Zeiteinheit. Das führt zu einer längeren Flugdauer, offensichtlich sind die Drohnen aus ergonomischer Sicht gut angepasst.

Trockengewicht des Körpers / Flügelfläche / Kraftüberschuss / Apis Drohnen / sexueller Dimorphismus

\section{REFERENCES}

Coelho J.R., Mitton J.B. (1988) Oxygen consumption during hovering is associated with genetic variation of enzymes in honeybees, Funct. Ecol. 2, 141-146.

Dulta P.C., Verma L.R. (1987) Comparative biometric studies on flight muscles of honeybees in the genus, Apis, J. Apic. Res. 26, 205-209.
Gries M. (1997) Vergleichende Untersuchungen zum Flugverhalten von Drohnen der Gattung Apis bei der Königinverfolgung, Dissertation, department of Biology, Johann Wolfgang Goethe University, Frankfurt.

Harrison J.F., Nielsen D.I., Page R.E. (1996) Malate dehydrogenase phenotype, temperature and colony effects on flight metabolic rate in the honey-bee, Apis mellifera, Funct. Ecol. 10, $81-88$.

Hepburn H.R., Radloff S.E., Steele G.R., Brown R.E. (1998a) Dimensional aspects of flight in the honeybees of Africa, J. Apic. Res. 37, 147-154.

Hepburn H.R., Radloff S.E., Brown R.E., Youthed C., Illgner P.M. (1998b) Production of aerodynamic power in mountain honeybees (Apis mellifera), Naturwissenschaften 85, 389-390.

Hepburn H.R., Radloff S.E., Fuchs S. (1999) Flight machinery dimensions of honeybees, Apis mellifera, J. Comp. Physiol. B 169, 107-112.

Hepburn H.R., Radloff S.E., Oghiakhe S. (2000) Mountain honeybees of Africa, Apidologie 31, 205-221.

Koeniger G. (1991) Diversity in Apis mating systems, in: Smith D.R. (Ed.), Diversity of the Genus Apis, Westview Press, Boulder, Colorado, pp. 199212.

Koeniger G., Koeniger N., Tingek S., Kelitu A. (2000) Mating flights and sperm transfer in the dwarf honeybee Apis andreniformis (Smith, 1858), Apidologie 31, 301-312.

Nachtigall W., Rothe U., Feller P., Jungmann R. (1989) Flight of the honey bee III. Flight metabolic power calculated from gas analysis, thermoregulation and fuel consumption, J. Comp. Physiol. B 158, 729-737.

Palmer K.A., Oldroyd B.P. (2000) Evolution of multiple mating in the genus Apis, Apidologie 31, 235-248.

Radloff S.E., Hepburn H.R., Otis G.W. (2001) Flight machinery of honeybees (Hymenoptera: Apidae, Apis), Proc. 7th Int. Conf. Trop. Bees: Management and Diversity, Chiang Mai, March 2000, pp. 163-168.

Ruttner F. (1988) Biogeography and Taxonomy of Honeybees, Springer-Verlag, Berlin. 